\title{
ANALYSIS OF DIVIDEND POLICY THROUGH THE DETERMINANTS OF MANAGERIAL OWNERSHIP
}

\author{
Siti Asih \\ Universitas Baturaja, Sumatera Selatan \\ Email : sitisitiasih@gmail.com
}

\begin{abstract}
ABSTRAK
Salah satu faktor yang menarik hati investor adalah kebijakan deviden. Baiknya sistem bagi hasil mencerminkan kekuatan bisnis dan sistem manajemen yang kokoh, sehingga memungkinkan investasi masuk. Namun, dalam pelaksanannya kebijakan dividen sangat dipengaruhi oleh struktur kepemilikan dan keadaan internal perusahaan. Oleh karena itu, penelitian ini bertujuan menganalisis faktor mana yang memiliki probabilitas besar terhadap keputusan kebijakan divien pada perusahaan yang tergabung di LQ-45. Secara fundamental penelitian ini masuk pada kategori kuantitatif dengan teknik analisis regresi. Sebanyak 45 perusahaan dipilih secara selektif menggunakan teknik judgement. Temuan dari hasil analisis menegaskan bahwa faktor profitabilitas secara regresif memiliki hubungan yang paling baik dan bersifat positif. Artinya, kebijakan dividen sangat bergantung pada seberapa besar laba yang diperoleh. Sedangkan faktor EVA dan Perputaran Kas terbukti secara kuantitatif tidak menjadi faktor pertimbangan kuat dalam pembuatan dan pengambilan keputusan kebijakan dividen. Begitupun dengan kepemilikan manajerial, bahwa perusahaan yang tergabung di saham LQ-45 cenderung profesional dalam menentukan kebijakan dividen, sehingga aspek struktur manajerial tidak mempengaruhi kebijakan dividen. Namun demikian, secara simultan seluruh faktor memiliki kemungkinan positif dalam mempengaruhi kebijakan dividen. Ini artinya, keberadaan faktor perputaran kas, EPS, struktur kepemilikan manajemen dan EVA secara bersama-sama berkontribusi terhadap penentuan kebijakan dividen, namun tidak berdasarpan perspektif parisial.

Kata Kunci: Struktur Kepemilikan Manajemen, EPS, Perputaran Kas, EVA, Kebijakan Dividen
\end{abstract}

\begin{abstract}
One of the factors that attracts investors is dividend policy. A good profit-sharing system reflects the strength of the business and a solid management system, allowing investment to come in. However, in its implementation, dividend policy is strongly influenced by the ownership structure and internal conditions of the company. Therefore, this study aims to analyze which factors have a high probability of dividend policy decisions in companies that are members of LQ- 45 . Fundamentally, this research is included in the quantitative category with regression analysis techniques. A total of 45 companies were selected selectively using judgment techniques. The findings from the analysis confirm that the profitability factor regressively has the best and most positive relationship. That is, dividend policy is very dependent on how much profit is earned. Meanwhile, the EVA and Cash Turnover factors proved quantitatively not to be a strong consideration factor in making and making dividend policy decisions. Likewise with managerial ownership, that companies incorporated in LQ-45 shares tend to be professional in determining dividend policy, so that the managerial structure aspect does not affect dividend policy. However, simultaneously all factors have a positive possibility in influencing dividend policy. This means that the existence of cash turnover, EPS, management ownership structure and EVA together contributes to the determination of dividend policy, but is not based on a partial perspective.
\end{abstract}

Keywords: Management Ownership Structure, EPS, Cash Turnover, EVA, Dividend Policy 


\section{INTRODUCTION}

Dividend of data obtained from 45 issuers that existed at the LQ-45 index indicates that the data from the years 2016 to 2019 dividends have movement fluctuating . This study uses a population of 45 companies listed on the LQ-45 index on the Indonesia Stock Exchange and after sampling, there are 23 companies that meet the criteria set by the researcher, including those that are still active and consistent in distributing dividends during the study year.

Based on research data, the average graph of the DPR in the 2016-2019 period has increased every year. In 2016, the trend of dividend distribution to issuers on the LQ-45 index showed 6.735964655, in 2017 to 2019 it increased to 8.64862359, 10.09373893 and 11.93724545 , respectively. As we know, the decision to distribute dividends is not made by some companies. Some companies prefer to hold their profits for various reasons. However, with the increasing trend of dividend distribution on issuers on the LQ-45 index, it shows that issuers on the LQ-45 index are companies that have fairly good liquidity.

One of the things that underlies the dividend policy of a company is the Economic Value Added (EVA) [1]. Economic Value Added can be used as an illustration of the company's performance related to the dividend policy that will be taken by the company. Research data shows that many issuers on the LQ-45 index have an EVA value below 0 or negative. EVA is negative due to the high cost of capital in the form of debt, interest expense, and tax expense compared to the net profit generated by the company. This shows that in those years, the company made a profit but the company was not able to provide added economic value for the owners of capital. Of the 21 sample companies studied, only 4 companies had positive EVA values during 20162019, namely Indo Tambang Raya Megah, Matahari Department Store, Bukit Asam Coal Mine and Surya Citra Medika.

In addition to using Economic Value Added, company welfare can also be measured using Earning Per Share (EPS) [2]. It is important for companies to analyze EPS in determining the dividend policy to be taken. The research data shows that the EPS of LQ-45 index companies is in line with the trend of dividend distribution, where the value of earnings per share shows a number that fluctuates every year.

The company's ability to pay dividends can be described by cash flow. Cash flow can be a relevant measure for the company's used income. However, based on research data, it shows that several companies show negative net cash flow values, but are still accompanied by an increasing trend of dividend distribution [3].

Various company decisions including dividend policy will be taken by the company's management. Some managers who own shares in a company show that managers can have two roles in one company, namely as a manager and also as an investor. A manager who owns shares in his company or in other companies will of course have different interests from managers who do not own shares or are purely managers. Managers who have a role as shareholder clearly do not want the company to experience difficulties, especially in its financial condition, because the difficulties faced by the company will make its position as manager and shareholder threatened. Therefore, managerial ownership will have a very significant influence on company decisions in determining dividend policy where the policy is also taken by managers in the company [4].

\section{THEORY BASIS}

Managerial ownership is a description of the portion of share ownership by the company's management. This means that managers in the company have two dual roles, namely as managers and also as shareholders. Both of these roles will affect decision making related to dividend policy that will be taken by the manager because it 
will have an impact on himself as a shareholder while on the other hand, managers who are also shareholders must think about the interests of the company [5]. Managerial ownership will provide an overview related to how the manager's ability to take dividend policy if the company carries out activities that have the potential to increase economic value added and what if the company's activities do not add economic value to the company. The number of managers who take on the role of shareholders in a company, is expected to be able to provide a good stimulus for companies in encouraging companies to carry out activities that will provide added economic value for the company, so that this will have an impact on dividend distribution to shareholders. This will also provide benefits for the manager himself as a shareholder. This is in line with research conducted by Rahayu \& Rusliati, which states that Managerial Ownership is able to moderate the Effect of Economic Value Added on Dividend Policy [6].

According to Nachrowi, in investing in the Stock Exchange, investors will pay attention to several aspects, one of which is earnings per share [7]. EPS is one indicator that is determined by the company's profit, so that EPS can describe the company's performance. If a company's EPS shows a high number, then this will cause the company's stock price to tend to move up [8]. Managerial ownership in a company will encourage increased supervision of the company's performance, so that managerial ownership is believed to be able to influence the running of the company which in turn affects the company's performance so that it will increase the return on shares owned by the company and will have an impact on dividend policies to be taken by the company [9]. ].

The cash flow referred to in this study is the available cash flow and can be expected to maintain and increase cash flow [10]. The involvement of managers in managerial ownership of a company makes managers have the motivation to be careful in making policies, including dividend policy [11]. Managers who act as shareholders will provide important inputs related to the net cash flow available in the company [12].

\section{RESEARCH METHOD}

The population in this study were all companies on the LQ-45 index. Then, the population that has been collected is limited by a number of criteria:

1. The company is included in the LQ-45 index

2. The company is a company engaged in the non-financial sector

3. The company consistently distributes dividends during the research year

4. The company has a positive profit during the study period The

5. The company is listed as having shares owned by Management

Based on Based on the criteria above, in total there are 45 companies that are members of LQ45 shares, but only 23 companies that meet the requirements above. The instrument of this research is financial statement data taken in the last 4 years from 23 companies studied.

Based on the method of obtaining it, the research data is in the form of secondary data. Secondary data is data that refers to information collected from existing sources. Secondary data sources are company records or documentation, government publications, media industry analysis, websites, internet, and so on.

Because the data used in this study is panel data, the authors use the E-views 9 program in processing research data. To estimate the model coefficients with panel data, the e-views program provides several analytical techniques:

1. Descriptive Analysis

2. Selection of panel data regression

3. Classical assumption test 
4. Panel regression analysis consists of determinant, partial, and simultaneous tests.

5. Moderation regression test

\section{RESULTS AND DISCUSSION Descriptive Analysis}

The output of the descriptive statistical test shows that for the last 4 years (20162019) there are negative numbers on EVA and cash flow variables. Then the company that has the highest and positive EVA value is Astra International, Tbk in 2018. This shows that PT Astra International, Tbk in 2018 had a higher net profit compared to the cost of capital used to pay debts, interest expenses and tax expense. While the lowest EVA value and negative value was shown by PT Gudang Garam, Tbk in 2016. EVA which shows a negative value indicates that the high cost of capital used by the company compared to the net profit obtained and shows the company management's inability to provide added economic value for the owners. capital on the net profit it has [13].

Furthermore, the company that has the highest EPS value is PT Gudang Garam, Tbk in 2019. A high EPS value illustrates the better performance and level of profit earned on each unit of common stock [14]. While the lowest EPS value was owned by PT Pakuwon Jati, Tbk in 2016. The low EPS value indicates that the ability per share to generate low profits.

Furthermore, the highest cash flow value was owned by Matahari Department Store, Tbk in 2018. A high cash flow value indicates that the company has excess cash to pay dividends. While the lowest cash flow value was shown by PT Sri Rejeki Isman in 2019 , this shows that the company chooses to use its cash flow to fund projects that are used as company investments rather than paying dividends.

Then the value of the highest dividend policy is owned by PT Indotambang Raya Megah. This shows that the company allocates its net income to pay dividends and this is in line with investor expectations. Indofood Sukses Makmur has the lowest dividend policy value in 2016 . This shows that the company prefers to allocate its net income to retained earnings or other projects than to pay dividends.

\section{Selection of Panel Regression Model}

Theresults of the Chow test obtained a probability $F$ value of $0.0000<0.05$, then the test was carried out using the Fixed Effect Model. While the results of the Hausman test show the probability value of the cross section is $0.0184<0.05$. This means that at a significance level of $5 \%$, it is more effective to use the Fixed Effect Model approach than the Random Effect Model. So that the model in this study will be tested using the Fixed Effect Model.

\section{Regression Analysis}

The EVA variable test results show a probability value of 0.5194 or greater than 0.05 , it can be concluded that the Economic Value Added has no effect on Dividend Policy. This shows that the positive or negative EVA value has no effect on the dividend policy that will be taken by the company. EVA can be used as a signal because EVA is one of the company's performance measurement tools that considers the expectations of shareholders for their invested capital. However, this theory contradicts the trend of dividend distribution in LQ-45 index companies. Only 4 companies in the LQ-45 index show a positive EVA value but the trend of increasing dividends in the LQ-45 index has increased from 2016 to 2019. This shows that the high EVA value is not the only signal that can inform dividend policy. will be taken by the company. High or low EVA value has no effect on dividend policy [15].

The results of the EPS variable test show a probability value of 0.0252 or less than 0.05. This shows that Earning Per Share has a positive effect on Dividend Policy. Earning Per Share is also a ratio that shows how much profit is obtained by investors 
or shareholders per share, shareholders will be attracted by a high EPS value, the higher the EPS value of a company, the longer the investor will invest his shares. Companies on the LQ-45 index have an EPS value that increases every year, this is in line with the increasing value of the dividend payout ratio which describes the dividend policy taken by the company. This is based on the idea that the value of a company depends on the ability of the company's profits, where profit is a source of funds that will be used to pay dividends. The higher the EPS value, the greater the company's profit and will have an impact on increasing the amount of dividends that will be received by shareholders.

The results of the FCF variable test show a probability value of 0.1226 or greater than 0.05. This shows that Cash Flow has no effect on Dividend Policy. This study found that the high and low value of free cash flow did not affect the level of dividend distribution. This is reflected in the LQ-45 index company, in general the value of free cash flow owned shows a negative value but does not affect the increasing dividend policy during 2016 to 2019 . Free cash flow is not the only source of funds allocated for payments. dividends, the company has an external source of funds that can be used to make dividend payments.

\section{Moderation Regression Analysis}

Moderation test results show a probability value of 0.4526 or greater than 0.05 . This shows that managerial ownership is not able to moderate the effect of Cash Flow on Dividend Policy. Managerial ownership is the proportion of ownership owned by directors, commissioners and managers in a company. The LQ-45 index company shows a very small number of managerial ownership compared to other ownership portions. The small portion of managerial ownership in a company makes management have little voice in making decisions, including those related to dividend policy. This study finds results that indicate that the interaction of Managerial Ownership and Economic Value Added has no effect on dividend policy.

Moderation test results show a probability value of 0.4793 or greater than 0.05 . This shows that managerial ownership is not able to moderate the effect of Earning Per Share on Dividend Policy. Managerial ownership is the proportion of ownership owned by directors, commissioners and managers in a company. The LQ-45 index company shows a very small number of managerial ownership compared to other ownership portions. The small portion of managerial ownership in a company makes management have little voice in making decisions, including those related to dividend policy. This study found results indicating that companies with low levels of managerial ownership are unable to moderate the effect of the value of earnings per share on dividend policy that will be taken by the company.

Moderation test results show a probability value of 0.4793 or greater than 0.05 . This shows that managerial ownership is not able to moderate the effect of Cash Flow on Dividend Policy. Managerial ownership is the proportion of ownership owned by directors, commissioners and managers in a company. The LQ-45 index company shows a very small number of managerial ownership compared to other ownership portions. The small portion of managerial ownership in a company makes management have little voice in making decisions, including those related to the use of free cash flow to pay dividends, so that the interaction of managerial ownership and free cash flow has no effect on dividend policy.

\section{CONCLUSIONS}

This finding suggests several mathematical explanations, including:

1. In the partial test, it is proven that only earnings per share have an effect on dividend policy. This means that companies that are incorporated in LQ45 shares 
in Indonesia have good profit sharing capabilities, so they should be an investment choice.

2. In the simultaneous test there is a significant effect of all independent variables. That is, all independent variables in this study have a better role in influencing earnings policy, if they are in a joint position. So, in conclusion, the dividend distribution policy is more or less influenced by financial and non-financial factors.

3. In the moderation test, it is proven that the ownership structure cannot moderate the independent variable towards the dependent. This means that, directly or indirectly, the ownership structure of companies in Indonesia that are incorporated in LQ45 shares does not have a tendency to play a management role, with considerations that it can affect the company's financial condition in the future.

\section{REFERENCES}

[1] Khasanah, Z., Salam, A., \& Hakim, L. (2019). PENGARUH ECONOMIC VALUE ADDED DAN INVESMENT OPPORTUNITY SET TERHADAP KEBIJAKAN DIVIDEN (Studi Kasus pada Sektor Jasa yang Terdaftar di Bursa Efek Indonesia Periode 2013-2017). Jurnal Ekonomi dan Bisnis Indonesia, 4(2).

[2] Kurniawan, F. A., \& Binastuti, S. (2020). Pengaruh Profitabilitas, Leverage, Dan Likuiditas Terhadap Kebijakan Dividen Dan Dampaknya Pada Harga Saham (Stidi Kasus Pada Perusahaan Makanan Dan Minuman Yang Terdaftar Di Bursa Efek Indonesia). Jurnal Manajemen Universitas Gunadarma, 1-16.

[3] Rachmah, O. S., \& Riduwan, A. (2019). Pengaruh Laba Bersih, Arus Kas Operasi, Free Cash Flow Terhadap Kebijakan Dividen. Jurnal IImu Dan Riset Akuntansi (JIRA), 8(1).

[4] Sani, A., \& Irawan, I. (2021). Model Panel Regression: Pengaruh Economic Value Added (Eva), Market Value Added (Mva), Kebijakan Dividen Dan Kepemilikan Manajerial Terhadap Nilai Perusahaan Food And Beverage Di Bursa Efek Indonesia (Bei). Jurnal AKMAMI (Akuntansi Manajemen Ekonomi), 2(3), 598-610.

[5] Sari, V. K., \& Amah, N. (2019, November). PENGARUH EVA, FCF TERHADAP KEBIJAKAN DIVIDEN DENGAN KEPEMILIKAN MANAJERIAL SEBAGAI VARIABEL MODERASI. In SIMBA: Seminar Inovasi Manajemen, Bisnis, dan Akuntansi (Vol. 1).

[6] Rahayu, D., \& Rusliati, E. (2019). Kepemilikan Institusional, Kepemilikan Manajerial, dan Ukuran perusahaan Terhadap Kebijakan Dividen. Jurnal Riset Akuntansi Kontemporer, 11(1), 41-47.

[7] Absari, D. U. A. (2019). PENGARUH ECONOMIC VALAUE ADDED (EVA), MARKET VALUE ADDED (MVA), LAVERAGE DAN KEBIJAKAN DEVIDEN TERHADAP RETURN SAHAM PERIODE 2016-2018. Media Mahardhika, 18(1), 46-56.

[8] Muslimah, A. W. PENGARUH ARUS KAS OPERASI, LABA AKUNTANSI DAN FREE CASH FLOW TERHADAP KEBIJAKAN DIVIDEN. Jurnal Kajian Ilmiah Akuntansi Fakultas Ekonomi UNTAN (KIAFE), 10(4).

[9] Jovanka, J., Winerungan, R., \& Lalamentik, O. (2021). PENGARUH KEPEMILIKAN MANAJERIAL DAN PROFITABILITAS TERHADAP KEBIJAKAN DIVIDEN PADA PERUSAHAAN SEKTOR PERTAMBANGAN YANG TERDAFTAR DI BURSA EFEK INDONESIA (BEI) TAHUN 2010-2019. Jurnal Manajemen dan Bisnis, 6(3).

[10] Rusaini, W. (2019). Analisis Pengaruh Free Cash Flow, Profitabilitas, likuiditas Dan Kepemilikan Manajerial Terhadap Kebijakan Dividen Pada Perusahaan ProPerty \& Real Estate di Bursa Efek Indonesia. Kumpulan Karya IImiah Mahasiswa Fakultas Sosial Sains, 1(01). 
[11] Abdullah, M. F., Kusasi, F., \& Pratiwi, R. A. I. (2021). Implementasi Kesempatan Investasi, Free Cash Flow, Ukuran Perusahaan, Kepemilikan Institusional, Collateralizable Assets Dan Pengaruhnya Terhadap Kebijakan Dividen Pada Perusahaan Pelayaran Yang Terdaftar Di Bursa Efek Indonesia Periode 20162019. Student Online Journal (SOJ) UMRAH-Ekonomi, 2(1), 378-390.

[12] Bawamenewi, K., \& Afriyeni, A. (2019). Pengaruh Profitabilitas, Leverage, Dan Likuiditas Terhadap Kebijakan Dividen Pada Perusahaan Manufaktur Yang Terdaftar Di Bursa Efek Indonesia. Jurnal Pundi, 3(1).

[13] Emida, P. C., \& Budiarti, A. (2019). PENGARUH PROFITABILITAS, FREE CASH FLOW, DAN LIKUIDITAS TERHADAP KEBIJAKAN DIVIDEN PADA PERUSAHAAN MANUFAKTUR. Jurnal IImu dan Riset Manajemen (JIRM), 8(4).

[14] Wulandari, C. A., Oktavia, R., Farichah, F., \& Kusumaningrum, N. D. (2020). ANALISIS PENGARUH KEPEMILIKAN MANAJERIAL, CASH RATIOI, DEBT TO EQUITY RATIO DAN GROWTH OPPORTUNITY TERHADAP KEBIJAKAN DIVIDEN. Jurnal Akuntansi dan Keuangan, 25(2), 1-19.

[15] Karjono, A. (2020). PENGARUH CASH RATIO, NET PROFIT MARGIN, DEBT TO EQUITY RATIO, DAN FIRM SIZE TERHADAP KEBIJAKAN DIVIDEN. ESENSI: Jurnal Manajemen Bisnis, 22(3), 270-288. 